\title{
Characterization of Three Abundant mRNAs from Human Ovarian Granulosa Cells
}

\author{
G. RAPP, J. FREUDENSTEIN, J. KLAUDINY, J. MUCHA, F. WEMPE, \\ M. ZIMMER, ${ }^{*}$ and K.H. SCHEIT
}

\begin{abstract}
Three cDNA clones, pHGR122, pHGR11, and pHGR74 containing the coding information for abundant mRNAs were identified from a human ovarian granulosa cell cDNA library. Characterization by nucleotide sequencing revealed that pHGR122 was specific for a collagenase inhibitor and pHGR11 for melanoma-associated antigen ME491. Relative quantification by Northern analysis indicated that collagenase inhibitor mRNA is a major species in granulosa cells. This finding provides evidence for the origin of this protein in follicular fluid as a secretory product of granulosa cells. pHGR11 identified melanoma-associated antigen ME491 as the unexpected product of normal, noncarcinogenic, granulosa cells. pHGR74 has the complete coding information for an unknown protein. Three independent experiments: (i) cell-free translation of pHGR74 RNA; (ii) transcription of suitable restriction fragments followed by cell-free translation; (iii) hydrolysis of the cell-free translation product of pHGR74 RNA by endoproteinase Lys-C, identified one open reading frame coding for an acidic, highly hydrophilic protein of 111 amino acid residues. pHGR74 mRNA is expressed in human testis, prostate, seminal vesicle, and ovarian granulosa cells. A comparative Southern analysis indicates pHGR74 mRNA is species specific and encoded by a single-copy gene.
\end{abstract}

\section{INTRODUCTION}

A T MIDCYCLE of the human menstrual cycle, a surge of luteinizing hormone $(\mathrm{LH})$ leads to the rupture of a mature follicle with the release of the oocyte. Soon after ovulation, the corpus luteum forms from two types of follicular cells: the theca and the granulosa cells. Little is known about the functional role of the granulosa cells in the follicle. To characterize the metabolic potential of the granulosa cells, we have analyzed mRNAs by sequencing cDNA clones from a human ovarian granulosa cell cDNA library. Recently we reported the characterization of an mRNA encoding polyubiquitin (Einspanier et al., 1987a,b, 1989) and of a cDNA containing the full coding region of elongation factor 2 (Rapp et al., 1988, 1989). Employing cDNA inserts from a number of cDNA clones of a cDNA library as hybridization probes in Northern analysis, we identified three cDNA clones that represented abundant mRNAs in human ovarian granulosa cells. We report the characterization of these mRNAs by cDNA sequencing.

\section{MATERIALS AND METHODS}

The human granulosa cells were obtained from follicles of patients after ovarian superstimulation by clomiphene; the cells were purified by Percoll gradient centrifugation. Total RNA and poly(A) $)^{+}$NA from human granulosa cells were prepared as described (Einspanier et al., 1987b; Rapp et al., 1988).

The construction of the cDNA library from human ovarian granulosa cells is described elsewhere (Einspanier et al., 1987b; Rapp et al., 1988). Plasmid DNA was isolated according to the method of Birnboim and Doly (1979). From plasmids of recombinant clones of the human granulosa cell cDNA library containing cDNA inserts $\geq 1,000 \mathrm{bp}$, respective cDNA inserts were obtained by restriction with Bam HI. The Bam HI inserts were purified by trough elution on a $1 \%$ agarose gel.

DNA probes were ${ }^{32} \mathrm{P}$-labeled by random priming to a specific activity of $10^{8} \mathrm{cpm} / \mu \mathrm{g}$ employing a commercial kit (Amersham). For Northern-transfer analysis, RNA after

Max-Planck-Institut für Biophysikalische Chemie, Abt. Molekulare Biologie, 3400 Göttingen, West Germany.

*Max-Planck-Institut für experimentelle Medizin, Abt. Molekulare Neuroendokrinologie, 3400 Göttingen, West Germany. 
treatment by formaldehyde was electrophoresed in a $1 \%$ agarose gel (Maniatis et al., 1982) and transferred to GeneScreen membranes (NEN). For the hybridization of RNA blots with DNA probes we followed the procedure of Khandjian (1986). For relative quantification of specific mRNAs, a human elongation factor 2 probe comprising nucleotide residues $1-1,765$ of the amino-terminal coding region was employed in Northern analysis (Rapp et al., 1989). Relative intensities of signals in autoradiographs were determined by densitometry and corrected for the different lengths of the individual probes.

The cDNA inserts of clones pHGR122, pHGR11, and pHGR74 were subjected to sequencing employing shotgun cloning in M13mp18(RF) as well as M13mp19(RF) using Sau 3A, Hpa II, and Pst I digests. DNA sequencing was carried out by the dideoxy chain-termination method of Sanger et al. (1977).

A Hpa II-Bam HI fragment of pHGR74 was cloned into the polylinker of the Bluescript-vector (Stratagene) downstream from the T3 promoter. The insertion of the fragment into the vector was verified by partial sequencing. RNA specific for the Hpa II-Bam HI fragment of pHGR74 was transcribed from the construct employing T3 RNA polymerase according to published protocols (Melton et al., 1984; Hope and Struhl, 1985). pHGR74 specific RNA was translated in vitro using a commercial kit (Amersham).

Genomic DNAs from human, dog, hamster, rat, mouse, monkey, chicken, and Xenopus were prepared from blood anticoagulated with EDTA (Maniatis et al., 1982). For Southern blot analysis, DNA was digested with restriction enzymes, electrophoresed in $0.7 \%$ agarose, and transferred to nitrocellulose membranes (BAS 85, Schleicher \& Schuell) essentially as described (Southern, 1975; Maniatis et al., 1982). The blotting procedure was used with initial depurination by $\mathrm{HCl}$ treatment.

Hybridization was performed at $60^{\circ} \mathrm{C}$ under stringent conditions following the protocol of Church and Gilbert (1984). DNA probes were ${ }^{32} \mathrm{P}$-labeled by random priming to a specific activity of $4 \times 10^{8} \mathrm{cpm} / \mu \mathrm{g}$ employing a commercial kit (Amersham).

DNA and protein sequence analysis as well as sequence comparison were performed using the computer program of the University of Wisconsin Genetics Computer Group (Devereux et al., 1984).

\section{RESULTS}

cDNA inserts of a number of cDNA clones of a cDNA library from human ovarian granulosa cells were employed to probe a Northern blot of total RNA from human granulosa cells. By this approach three cDNA clones, pHGR122, pHGR11, and pHGR74, were identified which correspond to abundant mRNAs. The lengths of the respective cDNA inserts in these clones matched the size of the mRNA species detected by Northern analysis, implying that the cDNA sequences will very likely represent the full coding region of the mRNA. To characterize the three cDNA clones, restriction analysis and cDNA sequencing were performed.

\section{pHGR 122}

The cDNA insert of pHGR122 comprised $775 \mathrm{bp}$; in Northern analysis it detected an mRNA species of $\sim 800$ bp. The nucleotide sequence and the derived amino acid sequence are shown in Fig. 1. The sequence of pHGR122 was identical with the mRNA encoding the precursor of the human fibroblast collagenase inhibitor (Docherty et al., 1985; Gasson et al., 1985; Carmichael et al., 1986), comprising the complete $3^{\prime}$ untranslated region and a major part of the $5^{\prime}$ untranslated region.

\section{pHGR 11}

Northern analysis with the insert of pHGR11 identified an mRNA species of $\sim 900 \mathrm{bp}$. According to sequence analysis, the length of the cDNA insert was $852 \mathrm{bp}$. The cDNA sequence as well as the derived amino acid sequence (Fig. 2) for the open reading frame were in full agreement with that reported for melanoma-associated antigen ME491 (Hotta et al., 1988); compared to the published sequence (Hotta et al., 1988), the cDNA insert extends $23 \mathrm{bp}$ further to the $5^{\prime}$ end.

\section{pHGR74}

With cDNA insert of pHGR74 as hybridization probe an mRNA of $\sim 900 \mathrm{bp}$ was identified. Sequence analysis of the cDNA insert indicated a length of 897 bp (Figs. 3 and 4). Neither identity nor homology of the sequence of pHGR74 with sequences contained in updated DNA databases was observed. The sequence possesses a short poly(A) tail and a polyadenylation signal AATAAA located 14 bp upstream from the tail. From the sequence two

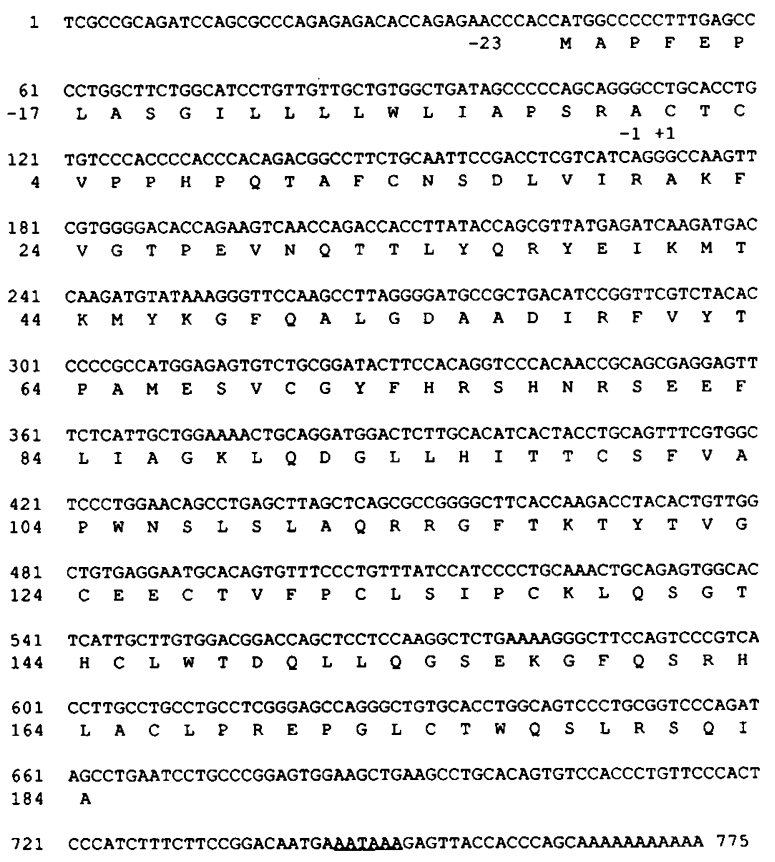

FIG. 1. Nucleotide sequence and deduced amino acid sequence of pHGR122. 


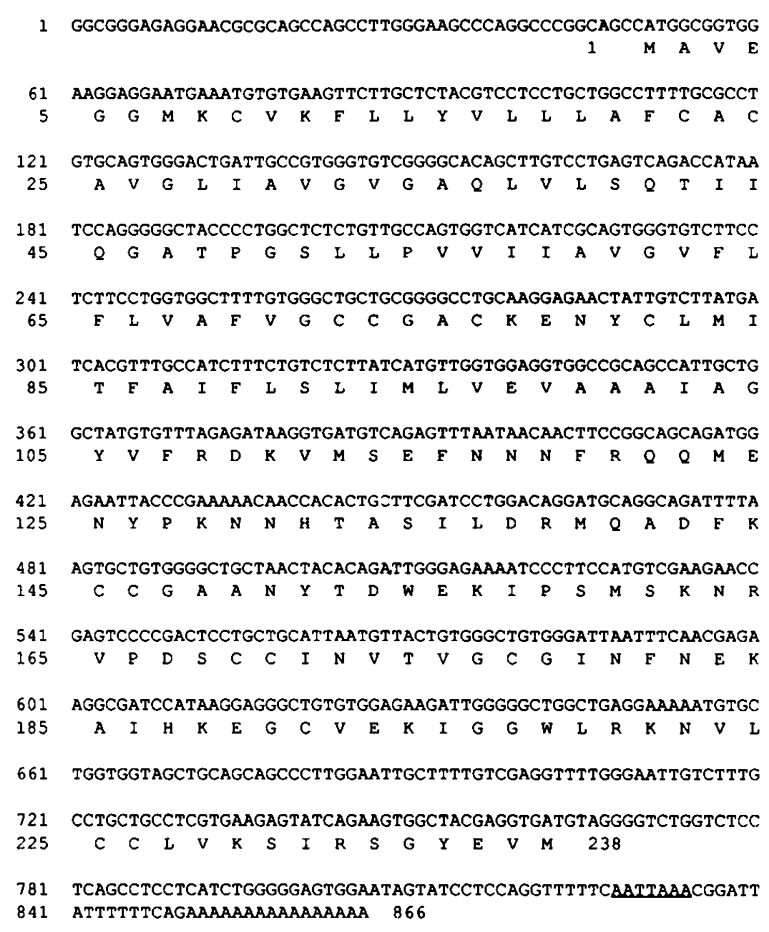

FIG. 2. Nucleotide sequence and deduced amino acid sequence of pHGR11.

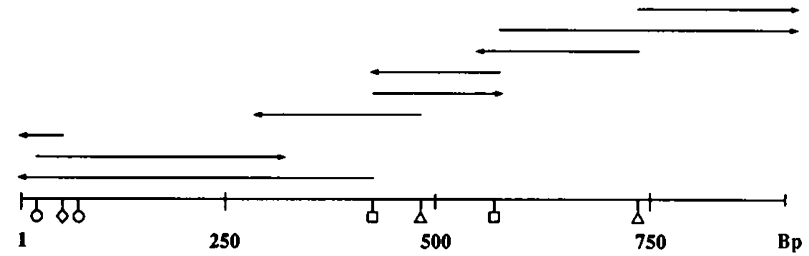

FIG. 3. Partial restriction map and strategy of nucleotide sequencing of pHGR74. Only restriction sites employed in sequencing are indicated: $\bigcirc, H p a \mathrm{II} ; \triangle$, Sau 3A; $\square$, Pst I; $\diamond$, Alu I. Horizontal arrows indicate extent and direction of sequencing.

longer open reading frames, ORF A and ORF B, each starting with a methionine codon, can be derived. Analysis of the CDNA sequence by program TESTCODE (Devereux $e t$ $a l ., 1984)$ identifies a potential protein coding region from positions 240 to 650 . Both ORF A as well as ORF B are located within this sequence region. ORF A codes for a protein of 111 amino acids, and ORF B for a protein of 57 amino acids. Two arguments favor the protein derived from ORF A: (i) in most mRNAs the first ATG of a long ORF is used as initiation codon in translation (Kozak, 1984); (ii) the ATG in ORF A is part of the sequence CATCATGG which has the characteristic features of a consensus sequence apparently controlling the translational effi- ciency of mammalian mRNAs (Kozak, 1984, 1987; Lütcke et al., 1987). The protein deduced from ORF A has a $M_{\mathrm{r}}$ of $12,985 \mathrm{Da}$ and rather hydrophilic features; this is complemented by results from a hydropathy analysis of the sequence using program PEPPLOT, which indicates the hydrophilic nature of putative protein A (data not shown). The calculated $\mathrm{p} I$ for protein $\mathrm{A}$ is $\mathbf{5 . 3 2}$. The hypothetical protein B derived from ORF B is also located within the predicted protein coding region; the calculated $M_{\mathrm{r}}$ for the protein is $6.8 \mathrm{kDa}$. The starting ATG of ORF B is part of a sequence AGAATGG which fulfills only minimal requirements of a consensus sequence: $a \mathrm{G}$ in position +4 and a purine nucleotide in position -3 . The protein sequences deduced from the open reading frames of either ORF A and ORF B displayed no homology to protein sequences in an updated data base.

To distinguish between the two putative ORFs we cloned the Hpa II-Bam HI fragment of pHGR74 comprising the sequence of the cDNA insert from position 22 to the $3^{\prime}$ end into the multicloning site downstream from the $\mathrm{T} 3$ promoter of the Bluescript vector. The correct insertion of the fragment was confirmed by sequencing. From this construct, RNA was prepared by transcription with T3 RNA polymerase and subjected to cell-free translation. Results depicted in Fig. 5 indicate that the RNA obtained by transcription of the complete coding region of pHGR74 led to one single protein of apparent $M_{\mathrm{r}} 18 \mathrm{kDa}$ in cell-free translation. From the size of the polypeptide, we conclude that it is derived from ORF A. Attempts to subject the protein obtained to cell-free processing by a microsomal membrane fraction failed. Thus, the protein may be a cellular protein.

The specificity of cell-free translation was investigated by restriction endonuclease digestion of the Bluescript/ pHGR74 construct. For this purpose the following suitable
1 ACCCCATCCCCCACTCCTATACCGGTCCTCCATTTTGGTGCCTGCAAAGCTCTGGGAAAG 61 AATCCCGGGAAACGAAAAATGGTGGGTTTGGGGGAAGGGAGGTAAGGGAGAAAGCTGGA 121 GGGAGGGGCTTTAATTGGAGGCCCCGTAGAGGACGCGCGGAACTTCTAAGGTGGGAAAAA 181 ACGAAATTAAAAAATCCTTTGATATCAGGGCTCTGAATCCTGCTGGTCAGAGCACCAAGC 241 ATTCAGTCTCTCTCCTTGCCTTTGTCTTACTTGTGTTCAAAGAAAAACAACCAGAAAAAA 301 AAAATCTCATCATGGCAAATATTCACCAGGAAAACGAAGAGATGGAGCAGCCTATGCAGA $\begin{array}{llllllllllllllllll}1 & M & A & N & I & H & Q & E & N & E & E & M & E & Q & P & M & Q & N\end{array}$ 361 ATGGAGAGGAAGACCGCCCTTTGGGAGGAGGTGAAGGCCACCAGCCTGCAGGAAATCGAC $\begin{array}{lllllllllllllllllllll}18 & G & E & E & D & R & P & \text { L } & G & G & G & E & G & H & Q & P & A & G & N & R & R\end{array}$ 421 GGGGACAGGCTCGCCGACTTGCCCCTAATTTTCGATGGGCCATACCCAATAGGCAGATCA $\begin{array}{lllllllllllllllllllll}38 & G & Q & A & R & R & L & A & P & N & F & R & W & A & I & P & N & R & Q & I & N\end{array}$ $\begin{array}{llllllllllllllllllllll}21 & G & D & R & \text { L } & \text { A } & \text { D } & \text { L } & \text { P } & \text { L } & \text { I } & \text { F } & \text { D } & G & \text { P } & \text { Y } & \text { P } & \text { I } & G & R & S\end{array}$ 481 ATGATGGGATGGGTGGAGATGGAGATGATATGGAAATATTCATGGAGGAGATGAGAGAAA $\begin{array}{llllllllllllllllllllll}58 & D & G & M & G & G & D & G & D & D & M & E & I & F & M & E & E & M & R & E & I\end{array}$

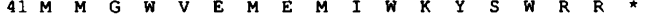

541 TCAGAAGAAAACTTAGGGAGCTGCAGTTGAGGAATTGTCTGCGTATCCTTATGGGGGAGC $\begin{array}{lllllllllllllllllllllll}78 & R & R & K & L & R & E & L & Q & L & R & N & C & L & R & I & L & M & G & E & L\end{array}$ 601 TCTCTAATCACCATGACCATCATGATGAATTTTGCCTTATGCCTTGACTCCTGCCATTTA

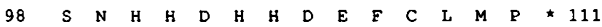

661 TCATGAGATTAATACTGTGATTCCCGCTGTTTTCTTTTTCCTTGCATTTTCCTAATATGC 721 CTTTACTGATCCGTTTGCTGTGAACCCTATGTTATTTCCATGTGTCAAGTGGGTCTTGTG 781 TTGCCAGCTTCTATTTGAAGATTGCCTTTGCACTCAGTGTAAGTTTCTGTCAGCAGTAGT 841 TTCACCCATTTGCATGGAAAAATTTAAAGCTAATAAAGCAATTTAAAAAGCAAAAAA

FIG. 4. Nucleotide sequence and deduced amino acid sequence of pHGR74. A, open reading frame A; B, open reading frame $B$. The polyadenylation signal is underlined. 


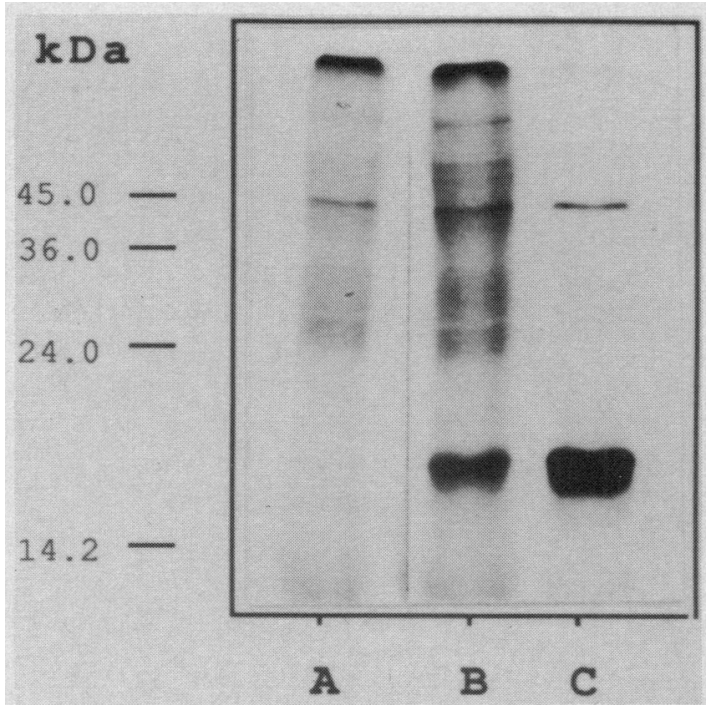

FIG. 5. Cell-free translation of pHGR74-specific RNA. Lane A, Translation in presence of microsomal membrane preparation without pHGR74-specific RNA; lane B, translation and processing of pHGR74-specific RNA; lane C, translation of pHGR74-specific RNA. A $15 \%$ gel was employed for $\mathrm{NaDodSO}_{4} /$ polyacrylamide gel electrophoresis.

restriction sites were chosen: a unique $E c o \mathrm{RV}$ site, located at position 203 (see Fig. 4) ahead of ORF A and two sites for $B s p$ HI. The latter enzyme cuts at positions $620,27 \mathrm{bp}$ before the end of ORF A, and at position $661,24 \mathrm{bp}$ after $\mathrm{ORF} A$. Following complete digestion by $E c o \mathrm{RV}$ and partial digestion by $B s p$ HI, transcription was performed and the resulting RNAs subjected to cell-free translation. Results of these experiments are shown in Fig. 6. Digestion with Eco RV completely abolished translation. In the case of partial digestion by Bsp $\mathrm{HI}$, the major product of cell-free translation was a polypeptide $\sim 1000 \mathrm{Da}$ shorter than the complete product of $M_{\mathrm{r}} 18 \mathrm{kDa}$ which was also synthesized.

The identification of the cell-free translation product as protein derived from ORF A was attempted by another independent approach. A unique feature of the amino acid sequence of protein $A$ is the presence of a single lysine residue at position 80; in contrast, the sequence of protein $B$ contains lysine moieties at positions 4,12 , and 32 , respectively. Hydrolysis of the cell-free translation product of pHGR74 RNA by endoproteinase Lys-C should therefore allow to identify the translation product as either protein $\mathrm{A}$ or $\mathbf{B}$, respectively. In the case of protein A, two fragments would be expected with a theoretical size of $9.2 \mathrm{kDa}$ and $3.6 \mathrm{kDa}$. As shown in Fig. 7 hydrolysis by endoproteinase Lys-C produced two fragments of apparent $M_{\mathrm{r}} 14.5 \mathrm{kDa}$ and $4 \mathrm{kDa}$ besides residual uncleaved protein A of $M_{\mathrm{r}} 18 \mathrm{kDa}$.

Northern analysis (Fig. 8) shows that pHGR74 mRNA of $900 \mathrm{bp}$ is expressed in human ovarian granulosa cells, human testis, human prostate, and human seminal vesicle. Northern analysis determined the relative abundancy of the mRNAs for pHGR122, pHGR11, and pHGR74 in human granulosa cells with respect to EF2-specific mRNA

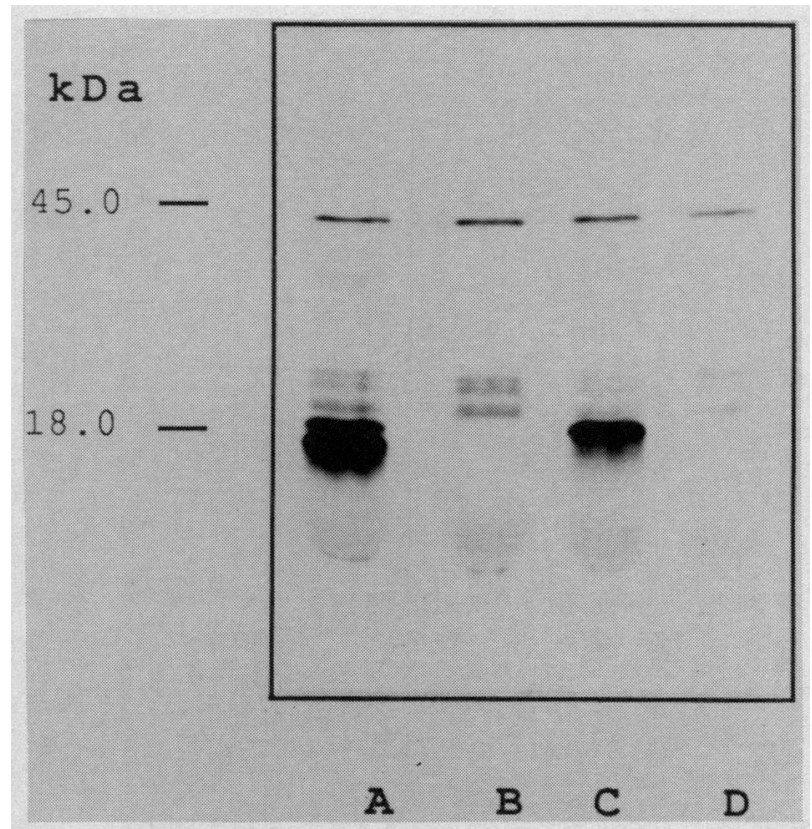

FIG. 6. Cell-free translation of mRNAs derived from restricted Bluescript/pHGR74 construct. Lane A, Construct treated with Bsp HI; lane B, construct treated with Eco $\mathrm{RV}$; lane $\mathrm{C}$, intact construct; lane $\mathrm{D}$, control without RNA. A $15 \%$ polyacrylamide $\mathrm{NaDodSO}_{4}$ gel was employed.

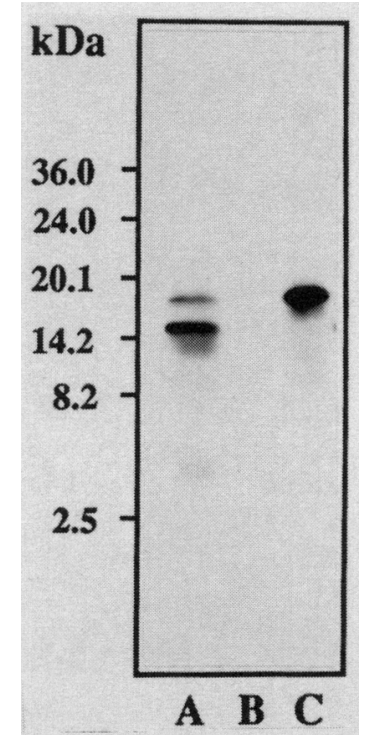

FIG. 7. Fragmentation of the cell-free translation product derived from pHGR74-specific RNA by endoproteinase Lys-C. A $17.5 \%$ polyacrylamide $\mathrm{NaDodSO}_{4}$ gel was employed. Hydrolysis by endoproteinase Lys-C was performed in $25 \mathrm{mM}$ Tris- $\mathrm{HCl} \mathrm{pH} 8.5$ at a concentration of 1 $\mu \mathrm{g} / 25 \mu \mathrm{l}$ for $90 \mathrm{~min}$ at $37^{\circ} \mathrm{C}$. Lane A, Cell-free translation product after treatment with endoproteinase Lys-C; lane $B$, cell-free translation mixture obtained in absence of pHGR74-specific RNA and treated with endoproteinase Lys-C; lane C, cell-free translation product of pHGR74specific RNA without proteinase Lys-C treatment. 
(Fig. 9). The appearance of an additional signal of 2,900 bp in case of hybridization with pHGR 122 could be unprocessed mRNA, due to the fact that total RNA was employed in Northern analysis. The Northern blot depicted in Fig. 9 was quantitated by densitometry; the results are detailed in Table 1.

The cDNA insert of pHGR74 was used for Southern analysis of human genomic DNA digested with $P v u$ II, Hind III, Bam HI, and $B g l$ II, enzymes not cutting within the cDNA sequence. In all cases only one fragment was detected by hybridization. From these results we tentatively infer that there is only one pHGR74-specific gene per haploid genome. Genomic DNAs from dog, hamster, rat, mouse, monkey, and human were digested with Eco RI and subjected to comparative Southern analysis employing the pHGR74 cDNA insert as probe. Hybridization under stringent conditions yielded only significant hybridization with human DNA (4.5 kb). From this result it appears that pHGR74 may represent a species-specific mRNA (Fig. 10).

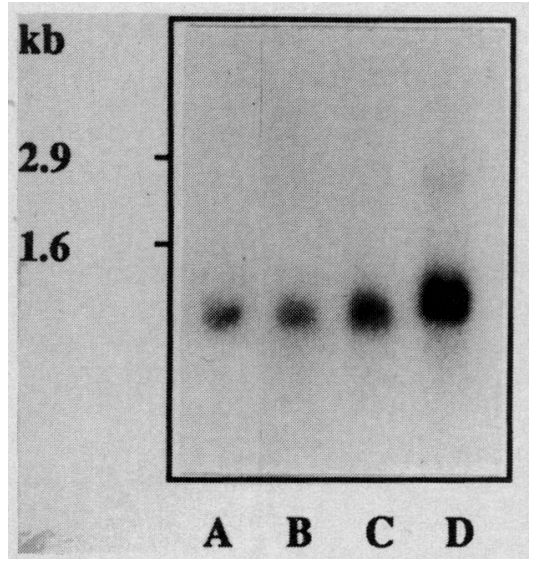

FIG. 8. Northern analysis. Hybridization was carried out with the Bam HI insert of pHGR74. In each of the following experiments, $10 \mu \mathrm{g}$ of total RNA each was employed. Lane A, Human testis; lane B, human prostate; lane C, human seminal vesicle; lane $D$, human ovarian granulosa cells. The size of the pHGR74-specific mRNA was estimated to $900 \mathrm{bp}$.

\section{DISCUSSION}

Ovulation appears to be facilitated by degradation of the extracellular matrix at the follicular apex, which in part results from the action of the metalloproteinase collagenase (Espey, 1980). Biochemical studies have demonstrated increasing collagenase activity during the preovulatory period, supporting this concept (Reich et al., 1985). The preovulatory increase in collagenase activity is stimulated by the LH surge (Reich et al., 1985; Curry et al., 1986); mechanisms controlling collagenase function in ovulation are, however, unknown. In other tissues, collagenase activity is regulated by several classes of metalloproteinase inhibitors such as $\alpha_{2}$-macroglobulin and tissue inhibitors of metalloproteinases. The latter class of inhibitors possesses a range of molecular weights of 25-30 kDa. Recently, Curry et al. (1988) identified and characterized a metalloproteinase inhibitor activity in human ovarian follicular fluid of $M_{\mathrm{r}}$ $28 \mathrm{kDa}$ with the properties of a glycoprotein. Although no at-

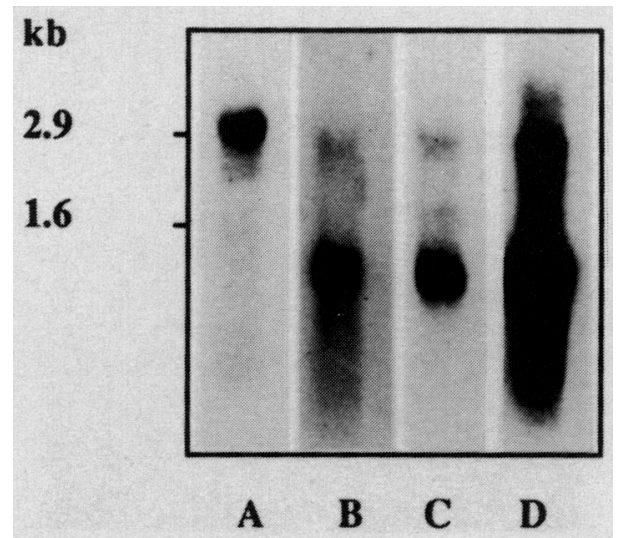

FIG. 9. Expression of pHGR11, pHGR74, pHGR122 mRNAs in human ovarian granulosa cells. Northern analysis was performed employing $10 \mu \mathrm{g}$ of total RNA per lane. The Bam HI inserts of clones pHGR11, pHGR74, and pHGR122 were labeled and 30 ng each was employed for hybridization. A PCR fragment of human elongation factor 2 comprising residues 1-1,765 was used as a control. Lane A, Human elongation factor 2; lane B, pHGR11; lane C, pHGR74; lane D, pHGR122.

Table 1. Determination of Relative mRNA Levels by Northern ANalysis

\begin{tabular}{|c|c|c|c|c|}
\hline Clone & $m R N A$ & Relative amount a & $\begin{array}{l}\text { Percent of } \\
\text { total } m R N A^{\mathrm{b}}\end{array}$ & Size $(b p)$ \\
\hline & EF2 & 1 & 0.1 & 3,100 \\
\hline pHGR122 & Collagenase inhibitor & 19.8 & 2 & 800 \\
\hline pHGR11 & $\begin{array}{l}\text { Melanoma-associated antigen } \\
\text { ME } 491\end{array}$ & 2 & 0.2 & 900 \\
\hline pHGR74 & Putative protein ORF A & 2.8 & 0.28 & 900 \\
\hline
\end{tabular}




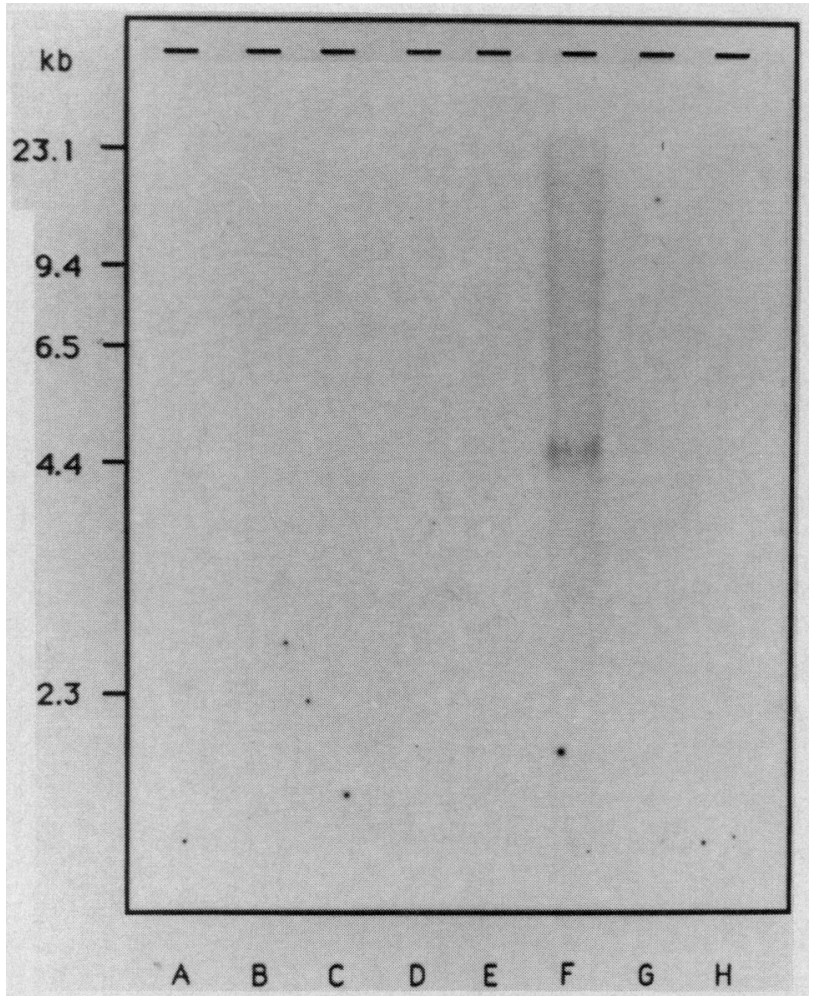

FIG. 10. Comparative genomic analysis. Each lane contains $10 \mu \mathrm{g}$ of the respective genomic DNA digested by Eco RV. Lane A, dog; lane $B$, hamster; lane $C$, rat; lane D, mouse; lane $\mathrm{E}$, monkey; lane $\mathrm{F}$, human; lane $\mathrm{G}$, chicken; lane H, Xenopus. The Bam HI insert of pHGR74 was employed as a hybridization probe.

tempts were undertaken to elucidate the origin of this inhibitor activity, these authors hypothesized that it might be produiced by granulosa cells. The work of Carmichael et al. (1986) and our present results strongly suggest that the collagenase inhibiting human follicular fluid glycoprotein is identical to human fibroblast collagenase inhibitor and that granulosa cells are the source for collagenase inhibitor in human ovarian follicles.

For melanoma, a pigmented cutaneous lesion, a detailed model of melanocytic tumor progression was developed (Clark et al., 1984). A large number of monoclonal antibodies against melanoma-associated antigens have been characterized (Atkinson et al., 1984; Herlyn et al., 1985). The antigen ME491 appears to be a marker for the early stages of tumor progression of human melanoma (Atkinson et al., 1984, 1985). ME491 is also expressed in adenocarcinomas of the colon and the prostate (Atkinson et al., 1985; Ernst et al., 1986). According to biochemical studies, antigen ME491 is a membrane-bound glycoprotein. Hotta et al. (1988) observed sequences highly homologous to ME491 mRNA in genomic DNAs of other species besides human. Our results indicate that the mRNA for this antigen is present in granulosa cells derived from normal human follicles and very likely is also translated. Hence, this would be the first report of the existence of antigen ME491 in apparently normal cells.
The putative protein derived from ORF A of pHGR74 appears to be a cellular protein. The discrepancy between the apparent $M_{\mathrm{r}}$ of $18 \mathrm{kDa}$ as determined by $\mathrm{NaDodSO}_{4} /$ polyacrylamide gel electrophoresis compared to the calculated value of $12,985 \mathrm{Da}$ seems to be a common problem and numerous cases could be cited; it may suffice to mention some recent findings of similar type (Mbikay et al., 1987; Scheit et al., 1988). Furthermore, the translational product of pHGR74 is an acidic protein as indicated by its low pI value; Kimelman et al. (1984) state that aberrantly high $M_{\mathrm{r}}$ values may be related to highly acidic isoelectric points.

Two independent approaches, transcription of suitable restriction fragments followed by cell-free translation and hydrolysis of the cell-free translation product of pHGR74 derived RNA by endoproteinase Lys-C, support the identification of protein A derived from pHGR74 as a hitherto unknown cellular protein.

\section{ACKNOWLEDGMENTS}

We appreciate the expert technical assistance by $J$. Dichter. This work was supported by the Bundesministerium für Forschung and Technologie grant 0706506 under the project "Regulation of Ovary Function."

\section{REFERENCES}

ATKINSON, B., ERNST, C.S., GHRIST, B.F.D., HERLYN, M., BLASCYK, M., ROSS, A.H., HERLYN, D., STEPLEWSKI, Z., and KOPROWSKI, H. (1984). Identification of melanoma-associated antigens using fixed tissue screening of antibodies. Cancer Res. 44, 2577-2581.

ATKINSON, B., ERNST, C.S., GHRIST, B.F.D., ROSS, A.H., CLARK, W.H., HERLYN, M., HERLYN, D., MAUL, G., STEPLEWSKI, Z., and KOPROWSKI, H. (1985). Monoclonal antibody to a highly glycosylated protein reacts in fixed tissue with melanomna and other tumors. Hybridoma 4, 243-255.

BIRNBOIM, H.C., and DOLY, J. (1979). A rapid alkaline extraction procedure for screening recombinant plasmid DNA. Nucleic Acids Res. 7, 1503-1523.

CARMICHAEL, D.F., SOMMER, A., THOMPSON, R.C., ANDERSON, D.C., SMITH, C.G., WELGUS, H.G., and STRICKLIN, G.P. (1986). Primary structure and cDNA cloning of human fibroblast collagenase inhibitor. Proc. Natl. Acad. Sci. USA 83, 2407-2411.

CLARK, W.H., ELDER, D.E., GUERRY, D.IV, EPSTEIN, M.N., GREEN, M.H., and VAN HORN, M. (1984). The development and subsequent cellular evolution of the primary human cutaneous malignant melanomas. Hum. Pathol 15, $1147-1165$.

CHURCH, G.M., and GILBERT, W. (1984). Genomic sequencing. Proc. Natl. Acad. Sci. USA 81, 1991-1995.

CURRY, T.E. JR., CLARK, M.R., DEAN, D.D., WOESSNER, J.F. JR., and LE MAIRE, W.G. (1986). The preovulatory increase in ovarian collagenase activity in the rat is independent of prostaglandin production. Endocrinology 123, 1823-1828.

CURRY, T.E. JR., SANDERS, S.L., PEDIGO, N.G., ESTES, R.S., WILSON, E.A., and VERNON, M.M. (1988). Identification and characterisation of metalloproteinase inhibitor activity in human ovarian follicular fluid. Endocrinology 123, 1611-1618. 
DEVEREUX, J., HAEBERLI, P., and SMITHIES, O. (1984). A comprehensive set of sequence analysis programs for the VAX. Nucleic Acids Res. 12, 387-395.

DOCHERTY, A.J.P., LYONS, A., SMITH, B.J., WEIGHT, E., STEPHENS, P.E., HARRIS, T.J.R., MURPHY, G., and REYNOLDS, J.J. (1985). Sequence of human tissue inhibitor of metalloproteinases and its identity to erythroid-potentiating activity. Nature 318, 66-69.

EINSPANIER, R., SHARMA, H.S., and SCHEIT, K.H. (1987a). An mRNA encoding poly-ubiquitin in porcine corpus luteum: Identification by cDNA cloning and sequencing. DNA 6, 395-400.

EINSPANIER, R., SHARMA, H.S., and SCHEIT, K.H. (1987b). Cloning and sequence analysis of a cDNA encoding poly-ubiquitin in human ovarian granulosa cells. Biochem. Biophys. Res. Commun. 147, 581-587.

EINSPANIER, R., SHARMA, H.S., and SCHEIT, K.H. (1989). The characterisation of ubiquitin-mRNAs in ovarian cells. In Reproductive Biology and Medicine. F. Holstein, D. Graesslin, and K.D. Voigt, eds. Diesbach Verlag.

ERNST, C.S., SHEN, J.-W., LITWIN, S., HERLYN, M., KOPROWSKI, H., and SEARS, H.F. (1986). Multiparameter evaluation of the expression in situ of normal and tumor-associated antigens in human colorectal carcinoma. J. Natl. Cancer Inst. 77, 387-395.

ESPEY, L.L. (1980). Ovulation as an inflammatory reaction. Biol. Reprod. 22, 73-106.

GASSON, J.C., GOLDE, D.W., KAUFMAN, S.E., WESTBROOK, C.A., HEWICK, R.J., WONG, G.G., TEMPLE, P.A., LEARY, A.C., BROWN, E.L., ORR, E.C., and CLARK, S.C. (1985). Molecular characterisation and expression of the gene encoding human erythroid-potentiating activity. Nature 315, 768-771.

HERLYN, M., THURIN, J., GALABAN, G., BENNICELLI, J.L., HERLYN, D. ELDER, D., BONDI, E., GUERRY, D., NOWELL, P., CLARK, W.H., and KOPROWSKI, H. (1985). Characteristics of cultured human melanocytes isolated from different stages of tumor progesssions. Cancer Res. 45, 5670-5676.

HOPE, I.A., and STRUHL, K. (1985). GCN4 protein, synthesized in vitro, binds HIS3 regulatory sequences: Implications for general control of amino acid biosynthetic genes in yeast. Cell 43, 177-188.

HOTTA, H., ROSS, A.H., HUEBNER, K., ISOBE, M., WENDEBORN, S., CHAO, M.V., RICCIARDI, R.P., TSUJIMOTO, Y., CROCE, C.M., and KOPROWSKI, H. (1988). Molecular cloning and characterisation of an antigen associated with early stages of melanoma tumor progression. Cancer Res. 44, 2955-2962.

KHANDJIAN, E.W. (1986). UV-cross linking of RNA to nylon membrane enhances hybridisation signals. Mol. Biol. Rep. 11, 107-115.

KIMELMAN, D.M., LUCHER, L.A., BRACKMANN, K.H., SYMINGTON, J.S., PTASHNE, M., and GREEN, M. (1984). Synthesis in $E$. coli of human adenovirus type 12 transforming proteins encoded by early region 1A $13 \mathrm{~S}$ mRNA and $12 \mathrm{~S}$ mRNA. Proc. Natl. Acad. Sci. USA 81, 6300-6304.

KOZAK, M. (1984). Compilation and analysis of sequences upstream from the translational start site in eucaryotic mRNAs. Nucleic Acids Res. 12, 857-872.
KOZAK, M. (1987). At least six nucleotides preceding the AUG initiator codon enhance translation in mammalian cells. J. Mol. Biol. 196, 947-950.

LÜTCKE, H.A., CHOW, H.C., MICKEL, F.S., MOSS, K.A., KERN, H.F., and SCHEELE, G.A. (1987). Selection of AUG initiation codons differs in plants and animals. EMBO J. 6, 43-48.

MANIATIS, T., FRITSCH, E.F., and SAMBROOK, J. (1982). Molecular Cloning: A Laboratory Manual. (Cold Spring Harbor Laboratory, Cold Spring Harbor, NY).

MBIKAY, M., NOLET, S., FOURNIER, S., BENJANNET, S., CHAPDELAINE, P., PARADIS, G., DUBE, J.Y., TREMBLAY, R., LAZURE, C., SAIDAH, N.G., and CHRETIEN, M. (1987). Molecular cloning and sequence of the cDNA for a 94-amino-acid seminal plasma protein secreted by the human prostate. DNA 6, 23-29.

MELTON, D.A., KRIEG, P.A., REBAGLIATI, M.R., MANIATIS, T., ZINN, K., and GREEN, M.R. (1984). Efficient in vitro synthesis of biologically active RNA and RNA hybridisation probes from plasmids containing a bacteriophage SP6 promoter. Nucleic Acids Res. 12, 7035-7056.

NAKANISHI, T., KOHNO, K., ISHIURA, M., OHASHI, H., and UCHIDA, T. (1988). Complete nucleotide sequence and characterisation of the 5 '-flanking region of mammalian elongation factor 2 gene. J. Biol. Chem. 263, 6384-6391.

RAPP, G., MUCHA, J., EINSPANIER, R., LUCK, R., and SCHEIT, K.H. (1988). Cloning and sequence analysis of a cDNA from human ovarian granulosa cells encoding the C-terminal part of human elongation factor 2. Biol. Chem. HoppeSeyler 369, 247-250.

RAPP, G., KLAUDINY, J., HAGENDORFF, G., LUCK, M.R., and SCHEIT, K.H. (1989). Complete sequence of the coding region of human elongation factor 2 by enzymatic amplification of cDNA from human ovarian granulosa cells. Biol. Chem. Hoppe-Seyler 370, 1071-1075.

REICH, R., TSAFRIRI, A., and MECHANIC, G.L. (1985). The involvement of collagenolysis in ovulation in the rat. Endocrinology 116, 522-527.

SANGER, F., NICKLEN, S., and COULSON, A.R. (1977). DNA sequencing with chain-terminating inhibitors. Proc. Natl. Acad. Sci. USA 74, 5463-5467.

SCHEIT, K.H., KEMME, M., AUMÜLLER, G., SEITZ, J., HAGENDORFF, G., and ZIMMER, M. (1988). The major protein of bull seminal plasma: Biosynthesis and biological function. Bios. Rep. 8, 589-608.

SOUTHERN, E. (1975). Detection of specific sequences among DNA fragments separated by gelelectrophoresis. J. Mol. Biol. 98, 503-517.

Address reprint requests to:
Prof. Dr. Karl Heinz Scheit
Max-Planck-Institut für biophysikalische Chemie
Am Fassberg
3400 Göttingen
West Germany

Received for publication December 5, 1989, and in revised form May 23, 1990. 